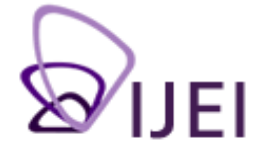

International

Journal for

Educational

Integrity

\title{
Integrity in higher education marketing? A typology of misleading data-based claims in the university prospectus
}

\author{
John Bradley \\ john.bradley@w3z.co.uk
}

Keywords: integrity, higher education, marketing, marketisation, prospectus

\begin{abstract}
This paper examines misleading marketing claims in UK university prospectuses. It reviews earlier studies suggesting that the imagery and language of university marketing can be misleading. It considers the use of data and statistics by universities in their advertising - a topic not previously studied. From a sample of UK university prospectuses a typology of misleading data-based marketing claims is proposed, with nine categories: omission of facts and selective reporting; misleading wording; misleading inferences about an attribute; misleading associations between attributes; misleading endorsements; claim-fact discrepancies; falsehoods; carefully crafted comparisons, and claims without a reference point. Because choosing a university is so important to students and because universities aspire to high ethical and scholarly standards, the issues raised by these findings are significant. The two bodies empowered to address this issue in the UK do not take a proactive approach and so it must fall to universities themselves to address the ethical challenges raised by misleading marketing.
\end{abstract}

\section{Introduction}

Figures often beguile me, particularly when I have the arranging of them myself. (Mark Twain, 1906)

One consequence of the move to the marketisation of higher education (HemsleyBrown, 2011; Molesworth, Nixon, \& Scullion, 2009; Sawyer, Johnson, \& Holub, 2009), has been an increasing emphasis by universities on how they promote themselves to potential students. The university prospectus that was once "a modestly produced booklet mostly written by academic staff" (Brockbank, 1996), has become a large illustrated glossy brochure with a parallel website designed by marketing professionals (Steele, 2009).

This marketing effort seeks to persuade potential students to attend the university. In the UK, attendance at university has been promoted by central government as serving the interests of the individual, the national economy and the cause of social justice (Bradley, 2012). It also, of course, serves the interests of the universities themselves, some of which face financial failure if recruitment is not successful (Curtis \& Meikle, 2007).

This paper questions the honesty and integrity of some university marketing. It reviews the critical literature on university marketing and reports on an exploratory study to examine misleading claims in UK university prospectuses. The study builds

The International Journal for Educational Integrity is available online at: http://www.ojs.unisa.edu.au/journals/index.php/IJEI/

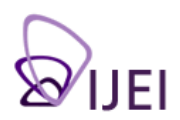


on the work of Gardener (1975) and Hastak and Mazis (2011) to propose a typology of misleading advertising claims in the university prospectus. The paper takes as its focus data-based claims in university marketing, as these have not previously been examined and appear to be regarded as if they are inherently truthful and objective.

\section{Previous studies}

Several studies have focused on the images and rhetoric in the prospectus and considered how these may be misleading. King (1987), interviewing marketing staff in US universities, reported "most people I interviewed...felt that while blatant misrepresentation was rare, 'massaging the facts' was part of the job". Webster (1992) commented wryly on the impression given by the American university prospectus: "Just as at Lake Wobegon, where all children are above average, so in college viewbook pictures and rhetoric, all institutions are above average - in fact, way above average".

Examining the images in US prospectuses, Hartley and Morphew (2008) observed: "viewbooks paint a hopeful, idealized and somewhat unrealistic portrait of undergraduate life... half the viewbooks had not a single picture of a student studying". In this they echo Klassen (2001), whose summary of the messages given by prospectus images was "lots of fun, not much work and no hassles". Askehave (2007), looking at European, Japanese and Australian examples, suggested that the modern university prospectus, in terms of its discourse, would be best understood as part of the tourist brochure genre.

As well as advertising puffery there are some reports of deliberate misrepresentation. In one widely publicised case, a US university doctored the cover photograph of their admissions brochure by digitally inserting a black student into a crowd of white football fans to make the student population appear more racially diverse (Claiborne, 2000). Subsequently, Pippert and Matchett (2010) examined a large sample of US viewbooks and concluded "Most college viewbooks did not provide accurate reflections of the racial and ethnic makeup of their student bodies". In the UK, Vasagar (2010) reported a suggestion of similar tactics in the prospectus of a high status English university.

Beyond misleading images and hyperbolic text there are accusations of a more fundamental misrepresentation. Gibbs (2007) identifies the pervasive distortion of the purposes of higher education in university marketing: ".... general shift from....higher education as a public good to one where it is viewed as an extension of self interested economic policy". Similarly, Astore (2009) asks what message we send about higher education "when we tell students that their college experience will enhance their 'advancement potential' [and] speak of the need for improved marketing and 'branding' of our institution so that we can better sell ourselves to students?".

\section{The turn to 'numbers'}

Unlike images and text, the use of numbers - data and statistics - in university marketing has received little academic attention. This is unfortunate, as three themes serve to make 'numbers' a focus of attention in UK university marketing.

As part of the continuing drive to widen participation in higher education there is a strand of research suggesting that it is lack of good quality information that underlies low participation levels by some social groups. Renfrew et al. (2010) in research commissioned by the Higher Education Funding Council for England (HEFCE), suggests that potential students from social groups with limited experience of higher education lack the basic factual information to help them make wise decisions. In this they echo earlier work by Archer and Hutchings (2000) and Connor and Dewson 
(2001), whose working class respondents told them that university marketing materials did not give them the information they needed.

In response, HEFCE and the equivalent funding bodies in Wales, Scotland and Northern Ireland determined that from September 2012 all UK universities will be required to display a 'key information set' [KIS] on the webpage for every course they provide. The KIS gives a standardised package of numerical data on: students' satisfaction, learning and teaching activities, assessment methods, professional accreditation, fees/financial support and employment/salary data. None of this KIS data, however, is required to be published in the university prospectuses which continue to quote a variety of data of their own. While KIS data is regulated and validated by HEFCE and the Higher Education Statistics Agency (HESA) there is no such oversight of the data universities publish in their prospectus or indeed elsewhere on their website.

A related driver for the interest in numbers comes from enthusiasts for the marketised model of education. Here the argument is made that "markets allocate efficiently only if the standard assumptions hold - perfect information, perfect competition, and no market failures" (Jongbloed \& Koelman, 2000). The deployment of data can be seen as an attempt to ensure the first of these economic assumptions is met - by providing supposedly 'perfect information'.

A third reason behind this turn to numbers in university marketing appears to be the advertising profession's belief in their persuasive power. George and Berry (1981) recommended their marketing colleagues to "rely on the tangibility of numbers [to provide] a concreteness that is often absent from service advertising". Similarly Mittall (1999) argues that numbers help to "meet the challenge of intangibility" when marketing something that can not be examined before purchase. In a classic paper Yalch and Elmore-Yalch (1984) reported experiments showing that 'numerical messages', using data such as percentages, were more persuasive than the same messages presented as narrative, particularly when the source of the claim was regarded as 'an expert'. What Porter (1995) calls "the prestige and power of quantification" is reflected in texts on experimental approaches to advertising, where 'numbers' are cited at the top of the list of 'what persuades' (Armstrong, 2010). In much of this marketing literature numerical information is treated as inherently objective - as if numbers 'speak for themselves' rather than being devices deployed in support of an argument.

Data use in university marketing, and the question of whether it can be misleading, does not appear to have been studied previously. However, there have been recent accusations that some institutions have tampered with numbers. Cloud and Shepherd (2012) and Murray (2012) reported that leading US law schools had fabricated data to improve their position in league tables. Similarly, a prominent US university admitted to inflating data over a ten year period, as part of a strategy to improve its league table position (Supiano, 2012). In the UK, one university had its National Student Survey data withdrawn after a covert recording revealed a staff member exhorting students to inflate their student satisfaction scores. Following their reports of these events the BBC noted that "in response, hundreds of students have e-mailed the BBC News website claiming this is a more widespread problem" (Coughlan, 2008).

\section{The regulation of UK university marketing}

In the UK, two organisations have a remit to consider the accuracy and honesty of university marketing - the Advertising Standards Authority (ASA) an 'industry selfregulating' body, and the Quality Assurance Agency for higher education (QAA) which inspects universities. 
Examination of the ASA archives reveals that in the period 2008 to 2012 nine complaints were made about university marketing (ASA, 2013). Seven of these were 'informally resolved' by the university withdrawing the material and no information on the nature of the complaint is publicly available. Two were 'investigated' and only one upheld - that being against the Department for Education for making the inaccurate claim that its new 'Diploma' qualification was 'accepted by all universities in their admission procedures' (ASA, 2009, 2010).

The QAA has a remit to ensure that 'Institutions' promotional materials and activities are accurate, relevant, current, accessible and provide information that will enable applicants to make informed decisions about their options" (QAA, 2008). It appears to discharge this responsibility principally by taking evidence from current students during an inspection. A summary of findings from 2004 to 2006 inspections mentions 14 instances from 59 inspections where, in response to student comments, marketing information was criticised by the inspectors. Some of these were quite significant criticisms including, "the institution's prospectus did not, in some respects, provide an accurate impression of students' experience"; "students had found the information provided prior to arrival was lacking in content, accuracy, relevance and quantity" and the institution needs to "ensure that all... promotional, marketing and advisory material ....are accurate, complete, unambiguous and do not mislead". The more recent summary report for inspections from 2007 to 2009 does not provide comparable detailed information (QAA, 2011).

Neither of these regulatory bodies appears to be proactive in policing the field. Both take a 'reactive' approach - the ASA responding to formal complaints and the QAA relying on student comments during the inspection process.

\section{Typologies of misleading advertising claims}

One line of research into misleading advertising has been the development of 'typologies'. In an early, much quoted, paper Gardener (1975) proposed a three-part typology of misleading advertising claims: "the unconscionable lie; the claim-fact discrepancy and the claim-belief interaction". Russo, Metcalf and Stephens, (1981) proposed a similar three-part typology which they termed "fraud; falsity and misleadingness". What these and other analyses (Preston, 1989; Richards, 1990) have in common is that they argue that an advertising claim does not have to be explicitly false to be misleading.

A comprehensive analysis of misleading claims is provided by Hastak and Mazis (2011). Their work is based on research for the US Food and Drug Administration and proposes a five-category typology of misleading advertising claims: omission of material facts; misleadingness due to semantic confusion; intra-attribute misleadingness; inter-attribute misleadingness; and source-based misleadingness.

The present study takes Gardener's and Hastak and Mazis's typologies as lenses through which to examine university marketing claims which make use of data or statistics. From this a new typology of 'misleading data-based claims' is proposed.

\section{The study}

This study looks at universities' use of numbers - data and statistics - in their marketing. This focus was chosen as:

- $\quad$ there are no previous studies on the use of numbers in university marketing;

- $\quad$ 'numbers' have been given a higher profile in UK university marketing following the introduction of KIS; 
- $\quad$ numbers appear to have the potential to be persuasive as an advertising tool; and

- $\quad$ it is possible to examine the accuracy of data-based claims in a way that is not always possible with subjective claims.

\section{Sample}

This study took a sample of eight universities (7\%) from the 116 UK universities listed in 'The Complete University Guide 2013', with the aid of a random number generator.

For each university the undergraduate prospectus was taken as the sampling frame. The prospectus has distinct advantages as a sample of university marketing effort. It has clear boundaries - you can see where it begins and ends - in contrast to a website where the number of pages and the ways they can be navigated is extensive. More importantly, the prospectus is the university's own sample of what information it wishes to put before prospective students.

Reay and David (2005) reported that even in the 21st century with the growth of online promotional materials, in the UK the most used source for information on universities was still the prospectus. Similar evidence of the continuing importance of the prospectus has been reported by Veloutsou and Paton (2005), Bennett and Kottasz (2006), Briggs and Wilson (2007), Steele $(2007,2009)$ and the UK Higher Education Academy (HEA, 2012).

\section{Methodology}

For each of the eight sample universities the undergraduate prospectus was downloaded in PDF format. The author then read each of these publications, cover to cover, identifying instances where the prospectus made a claim based on statistics or data. Each of these claims was recorded, together with the piece of text within which it occurred.

For the purposes of this study a 'data-based claim' was one which met one of the criteria:

- $\quad$ Numbers are quoted e.g. "You'll be at an international university with students from more than 120 countries"; "95\% of graduates were happy with their course"; or

- $\quad$ The claim implies a reference to data or statistics, typically with such terms as 'ranked', 'scored', 'rated', e.g. "The top ranked chemistry department in the Guardian University Guide”.

This process yielded a collection of 932 data-based claims. The number of claims ranged from a high status university that made only 21 claims in its very brief prospectus to a modern 'recruiting' university that made 287 (the majority of which were about the number of contact hours offered on every module and were excluded from the study). Aside from these two outliers, the number of claims for the other six universities was $55,64,71,104,153$, and 177 . These were then examined in the light of Gardener's (1975) and Hastak and Mazis's (2011) typologies of misleading claims. In order to understand a claim it was often necessary to check the claim against the source data - the league table being referred to, the results of the Research Assessment Exercise (RAE) or the National Student Survey (NSS). When this 'fact checking' did not yield a clear understanding of the claim the author wrote to the university under the terms of the Freedom of Information Act and asked them to 
provide the evidence for their claim or explain how they had interpreted the data in order to make the claim.

If a claim fitted the description of one of Gardener's or Hastak and Mazis's existing 'misleading claim types' it was assigned to that category. If, however, a claim appeared misleading but did not fit into an existing category a new category type was opened. Drawing on the methods of grounded theory analysis (Glaser \& Strauss, 1967) this process was iterative - moving constantly between the examples and the categories and continued until categories were 'saturated' - that is, no new categories were being found and the existing categories were well populated with examples.

The methodology is explicitly qualitative - it aims to provide a picture of the way misleading data-based claims are made. It describes the types of misleading claims that were found, rather than making assertions about the frequency with which different types were made.

Nevertheless, some quantitative observations can be made about the subject of the data-based claims examined. The six most frequent subjects of claims, in descending order, were the National Student Survey (143 claims, 15\%); the Research Assessment Exercise (104 claims, 11\%); the physical resources available at the university - buildings, libraries, laboratories (125 claims, 13\%); the employment prospects of graduates (93 claims, $10 \%$ ) the number, quality and qualifications of staff (88 claims, $9 \%$ ); and the university's position in published league tables (58 claims, $6 \%)$.

\section{Results}

The author has chosen not to name the universities in the study, and department names and other potentially identifiable references have been edited out. This decision was taken because any shortcomings identified in the integrity of these prospectuses are likely to be found more widely across the sector. As such, it seems unfair to name (and potentially shame) those institutions that were randomly selected for study.

In the typology that follows, the first five types are taken from Hastak and Mazis, types 6 and 7 are taken from Gardener and types 8 and 9 are proposed by the author. [One of Gardener's 'types' - 'claim-belief interaction' proved, in practice, to be dealt with by Hastak and Mazis's 'intra-attribute' and 'inter-attribute' misleadingness categories and so was omitted.]

\section{A typology of misleading data-based marketing claims in the university prospectus}

\section{Omission of material facts and selective reporting of data}

Hastak and Mazis define this as a claim where the advertiser fails to disclose information or limiting conditions that are necessary for a correct interpretation of the claim.

It is impossible to be sure how many examples of this type of flaw there are in the sample since it is difficult to detect when something is not being mentioned. Some examples, however, were quite clear.

Example 1a In one prospectus a standard format was adopted to describe each course. This comprised reference to NSS scores for the course and RAE results. So a typical entry read "Our [subject] students report satisfaction levels of $93 \%$ in the 
National Student Survey 2011. In the most recent independent survey of research quality, the RAE, [subject] research at [the university] was rated in the top ten in the UK". However for one department no such data was quoted. On inspecting the NSS and RAE data it transpired that the department was ranked in the third quartile of the NSS results and bottom of the RAE subject table.

Example 1b Most universities reported data that was positive about a course but none mentioned any unflattering data. For example a university claimed "Our [department] students report satisfaction levels of $93 \%$ in the National Student Survey 2011 " but did not mention figures on drop-out rates which showed that $20 \%$ of students did not continue into the second year of their course.

\section{Misleading wording}

Hastak and Mazis term this 'misleadingness due to semantic confusion' - claims where consumers may be misled by the use of confusing language which leads them to misunderstand the claim.

Example 2a A university claimed: "In 2010, 89\% of the School's graduates were in employment or further study within six months of graduation while others were taking time out to travel etc".

This statement would seem to imply that $89 \%$ of the school's graduates were "in employment or further study", with the remaining $11 \%$ "taking time out to travel etc.". An FOI request clarified that this was not the case. Of the 294 graduates, 253 responded to the survey. Of these 203 were employed, in further study or both; 24 were unemployed and seeking work; 15 were taking time out to travel and 16 were "not available for work". So $69 \%$ of the 2010 graduates were known to be in work or study - or put another way $80 \%$ of the graduates who responded to the survey were known to be in work or study. The figure in the prospectus of " $89 \%$ in employment or study" was achieved by calculating the 203 in work or study as a percentage of the 227 in work or study or unemployed and seeking work, and excluding from that calculation those who were traveling or were otherwise unavailable for work. The wording of the claim encourages a quite different interpretation and a typical prospective student would be likely to believe that $89 \%$ of the students who graduated in 2010 were in work or further study. In their response, the university suggested that "...the statement is perhaps confusing".

Example 2b "Students here are among the most satisfied in the UK; they have voted us among the country's top ten universities for student satisfaction in six out of the seven annual National Student Surveys carried out so far".

The university appears to claim that it has been in the top ten universities in the UK for student satisfaction for six out of seven years. It has not. As their FOI response confirmed, the university's claim hinges on the semantics of the terms 'UK' (United Kingdom) and 'country'. In a complexity that confuses many UK citizens the United Kingdom is technically a nation comprised of four countries (England, Scotland, Wales and Northern Ireland). The university was indeed in the top ten universities for student satisfaction for six out of seven years in England. The claim, however, cleverly elides from talking about the 'UK' to talking about the 'country' within the space of a single sentence. In doing so it manages to inflate its apparent achievement.

Example 2c A university claimed to be "one of the top five Northern universities for student satisfaction". However an FOI request revealed that this particular definition of 'northern' did not include any of the 9 universities in Greater Manchester, Liverpool or the Counties of Lancashire and Cumbria, which most readers would regard as being in the 'north of England.' 
Example 2d The wording of claims about national student survey results was sometimes potentially misleading. For example, one prospectus repeatedly used the formulation "Our [subject] students report satisfaction levels of $98 \%$ ". To those unfamiliar with the survey, this could sound as if students, asked to score their satisfaction on the course, had given it a rating of 98/100. In fact the statistic tells us that $98 \%$ of students who responded to the survey said that they "mostly agreed" or "definitely agreed" with the statement "overall I am satisfied with the quality of my course".

\section{Misleading inferences about an attribute}

Hastak and Mazis refer to this as 'intra-attribute misleadingness' - where a claim about an attribute leads to other, misleading, inferences about the same attribute.

Example 3a In the prospectuses a regular example of this is found in claims about the employment rate of graduates. The 2013 prospectuses were published in 2012 and much of the data they refer to was taken from the 2010 cohort of graduates. Readers of the 2013 prospectus will graduate in 2016 or 2017 . So claims about graduate employment in 2010 are used to infer what graduate employment in 2016 and 2017 will look like. The university that claimed "100 per cent of our [subject] graduates, seeking to enter employment or further study, are successful within six months of completing their course", encourages this misunderstanding by the use of the phrase "are successful" - a verb form that implies ongoing $100 \%$ success.

Example 3b One university provided a 'List of graduate salaries' which looked surprisingly high. On closer inspection, a footnote to the data explained that these were the average salaries of both undergraduate and postgraduate course leavers. Since the university provided a large number of part-time, mid-career masters courses, many of these postgraduates would be returning to existing well-paid posts. A school-leaver reading the table (and probably not noticing the footnote) would take the claim about 'graduate salaries' to infer that this was the sort of salary they might aspire to after an undergraduate degree. Since the prospectus was exclusively describing undergraduate degrees, this would have been a reasonable, but untrue, interpretation.

\section{Misleading associations between attributes}

Hastak and Mazis refer to this as 'inter-attribute misleadingness' - where a claim about one attribute encourages a belief about another attribute. The inference occurs because readers believe (rightly or wrongly) that the two attributes are correlated.

Example 4a "You will be taught by some of the best researchers in this field, who are ranked top in [the country] for research, in the most recent independent survey of research quality". So a claim about one attribute - the research prowess of staff in the department is presented to imply that another attribute - their teaching, will be of a high quality.

Example 4b A similar issue occurs when universities offer claims about the 'age' of their courses in a way that encourages a belief about the 'quality' of the course. For example: "Our expertise in professional training spans more than 30 years in [subject], 50 years in [subject], and 60 years in [subject]; heightening our reputation for producing graduates of the highest calibre".

\section{Misleading endorsements}

Hastak and Mazis describe this as this 'source based misleadingness' - a situation where the advertiser appears to be presenting an endorsement or evidence from an independent source but the endorsement or evidence turns out not to be independent. 
This study found many examples where claims appear to invoke an independent endorsement but which turn out to be based on the university's own manipulation of data. For all its other shortcomings, the RAE did not actually 'rank' universities or departments by creating a hierarchical table of results. That was left to the publishers of the university league tables who calculated a 'Grade Point Average' for each university and subject area and published corresponding 'RAE league tables'. In checking RAE related claims in prospectuses it became apparent that many claims did not correspond to the published league tables of RAE performance. Following FOI inquiries it transpired that many universities 'rework' the RAE data using their own criteria so as to place themselves in a more flattering position in league tables they have created themselves.

Example 5a "[Subject] at [university] is ranked in the top ten in the UK for research (RAE 2008)". Inspection of RAE data did not appear to confirm this claim. In response to an FOI request the university explained that when they calculated the data they began with the grade point average scores which placed them equal 14th. They then recalculated the table to give additional priority to $4^{*}$ graded research - this moved them up to being equal tenth with two others. They then further recalculated the data to take account of their having submitted more staff in that discipline, thus placing them tenth in the table they had thus created.

Example 5b One specialist department at a university found an easier way to move up the 'RAE table' for its research area was by disregarding research that was not submitted by a department of the same type as its own. This allowed it to claim that its research was "top in [the country] and joint top in the UK in the most recent independent survey of research quality, the RAE 2008" - rather than equal sixth with two others when compared to all departments that submitted research to that RAE subject area.

In both these examples the claim is presented as resting on 'RAE rankings' something that sounds independent. Most students are likely to assume that the 'ranking' has been undertaken as part of the RAE, or that it refers to rankings in the commercial league tables. In fact the source of the data is the university itself, which has massaged the RAE data to provide a more positive picture.

As Dean and Biswas (2001), have demonstrated, third party endorsements are a particularly persuasive strategy for increasing perceptions of 'quality'. As such, universities' strategies to present their own 'rankings' as if they were calculated independently are particularly concerning.

\section{Claim-fact discrepancy}

Gardener describes this type of claim as one where, while literally accurate, some degree of qualification is required for it to be properly understood. Without such qualification the claim, while true, is misleading.

Example 6a In their 2013 prospectus a university claimed "...our [department] teaching was rated as EXCELLENT - the top score". In response to an FOI inquiry the university revealed that the claim related to a Teaching Quality Assessment in 1994. Using 19 year old data, without making this clear to potential students, seems misleading.

Example 6b "Our [subject areas] students report satisfaction levels of $96 \%$ in the National Student Survey 2011". In fact the NSS survey reported scores of $89 \%$ and $92 \%$ for the two courses being described. The university explained in its FOI response that it had combined the figures from these two courses with a third course (not being described in this part of the prospectus) which had a $100 \%$ satisfaction score. The NSS figures for the two courses being described were thereby inflated. 
There is also a broader question about the qualifications that need to be made about any claim that refers to NSS data. Marsh (2007) and Cheng and Marsh (2010) have cast doubt on whether the survey provides useful measures of differences between courses and universities. Similarly, a report commissioned by HEFCE itself warned that some of the comparisons "made in published league tables, but also by institutions themselves... are strictly speaking outside the NSS's capability" (IOE, 2011).

\section{Falsehoods}

Gardener uses the provocative term 'unconscionable lies' for this category of claims that are simply untrue.

Example 7a One university claimed that "In a survey of international students at 59 UK universities, [the university] ranked highest for ... its emphasis on independent, flexible learning. Source: International Student Barometer 2010". The author examined the survey but could find no evidence of this. In response to an FOI inquiry the university confirmed that the survey in question had not in fact asked any questions about 'independent, flexible learning' and as such the claim was an error that they would remove from future marketing material.

Example 7b A university wrote "[The town] is one of the most cost effective cities in the UK in which to live. NatWest Student Index 2010". The claim was made twice in the prospectus, on one occasion with quotation marks around the phrase to suggest that it was a direct quote from the survey. Examination of the survey revealed that it made no reference to the town being a cost effective place to live. Indeed it seemed to give quite the opposite picture, placing it in the seventh decile. On inquiry the university responded that the claim was 'an error', caused by their misunderstanding of the results and offered an assurance that the claim would not be repeated.

Example 7c "We have twice been named 'Britain's friendliest university' in independent surveys". In reply to an FOI request the university disclosed that the 'independent survey' was an online poll on the Friends Reunited social website and in fact they had only been voted most friendly university once.

\section{The carefully crafted comparison}

Many claims are about a university's performance in comparison with other institutions. By carefully selecting the terms of that comparison it is possible to present a more favourable picture in a way that may be misleading.

Example 8a A university referred to itself as "in the country's top ten mainstream higher education institutions" thereby removing from the comparison an unknown number of competitor institutions that the university decided are not 'mainstream'.

Example 8b A university produced a table titled "Percentage of graduates, from Russell Group universities who were in employment or further study six months after graduating", in which the university ranked third. While ranking third in comparison with institutions in the high status 'Russell Group' appears impressive, if they had compared themselves to all universities they would have ranked 19th in the UK. So by carefully choosing who they compared themselves to they were able to inflate their achievements.

Example 8c A university claimed to be "ranked as the top modern university in [city] for [subject]". So three qualifiers - type of university, location and subject are applied before the course is 'top'. 


\section{Claims without a reference point}

Many claims offer data without any reference point for comparison. This makes them very difficult to evaluate and potentially misleading.

Example 9a "Investment in infrastructure, facilities and staff - some $£ 75$ million has been spent over the last five years, including almost $£ 25$ million on student accommodation". Without an understanding of how much a major university typically spends on 'infrastructure, facilities and staff' over a five year period there is no way of knowing if this apparently large figure is praiseworthy.

Similar claims leave the reader no wiser as to the scale of the achievement being reported: "The library houses more than a million books", "Last year we advertised more than 7,000 graduate positions", "The libraries provide access to 21,000 journals", "The School has a staff of more than 50 academics, including 14 professors", and "A package of more than $£ 20$ million in financial and student support over three years".

Example 9b "[Subject] research at [university] is rated in the top ten in the UK, according to the most recent independent survey of research quality". While it is true that the department was ranked equal tenth (and so technically in the top 11) in the UK, the claim lacks a reference point for the number of departments against which it is being compared. In this case there were 14 departments in this subject area of the RAE. So, if a reference point were given, the claim 'in the top ten' could alternatively be expressed as 'in the third quartile' or 'in the bottom half.'

\section{Conclusions and discussion}

This study suggests that UK university prospectuses provide examples of data-based marketing claims that are potentially misleading. Drawing on previous work, a tentative typology of misleading data-based claims is suggested. The examples illustrating this typology raise questions about the integrity and ethics of some university marketing.

The study can not tell us what effect misleading marketing has on potential students. There is evidence of young people's general scepticism about advertising (Boush, Friestad, \& Rose, 1994) as well as their sophistication in recognising the persuasive intent of advertisers (O'Donohoe, 2001). However, it is possible that marketing from universities is not viewed as being 'advertising' by its adolescent recipients.

Universities may be seen to be a reliable source of information and the prospectus as a 'factual account' of what the institution can offer. As such, university marketing may bypass the filter of scepticism through which young people typically perceive other advertisements.

There may also be different implications for the different type of claim made. A misleading claim about the status of the university's research programme may turn out to have less significance for the potential student than a misleading claim about the employment prospects of graduates. Additionally, it may matter relatively little when universities make misleading claims about their standing in NSS results. As Cheng and Marsh (2010) have demonstrated, while NSS data are statistically sound, the differences they reveal between universities are very small (less than $3 \%$ of the variance in student responses is accounted for by actual university differences).

There are reasons to argue that the marketing of higher education should aspire to higher ethical standards than marketing in general. Firstly, because what is being marketed is expensive, potentially life changing, and can not be tried out before it is 'purchased'. Secondly, because university marketing is directed, in part, at a 
potentially vulnerable group. Seventeen year-old young people from social backgrounds where there is little experience of higher education have limited sources of information on universities (Pugsley, 2004). Their parents, relatives and friends are unlikely to have been to university. They are likely to attend schools where the number of pupils considering higher education is small (Kintrea, StClair, \& Houston, 2011). As such, the prospectus may be their principal source of information (Connor \& Dewson, 2001). If they are to make wise life choices this information needs to be truthful, balanced and complete.

A third reason for universities to have particularly high standards for their marketing publications is that their status and reputation in society is built in part on having high standards of scholarship. This includes the careful collection and use of evidence, balanced and accurate reporting and the use of processes such as peer review to ensure rigour in what is published. As Sharrock (2010), noted: “... intellectual honesty and rigour are fundamental to the professional identity, social responsibility and public authority of researchers". Publications emanating from a university, including the prospectus, carry with them a public expectation that the claims they make are carefully presented, well evidenced and reputable.

The two bodies with regulatory responsibilities in the field, ASA and QAA, do not take a proactive approach and have limited impact on the accuracy of university marketing materials. Universities themselves, however, are well placed to address the issue of misleading advertising. They do not need to look far to find sound guidance on these issues. Guidelines for research ethics (UKIRO, 2009) and academic publication ethics (Roberts, 2009; Wager \& Kleinert, 2011) offer potential models for writing ethical marketing publications. In an earlier era, concerned academics in the US led a programme of voluntary peer review of university marketing publications and found the process to be "both straightforward and effective" (El-Khawas, 1977; Stark \& Marchese, 1978). A similar programme today would demonstrate universities' determination to ensure high ethical and scholarly standards in all the material published in their name.

\section{References}

Archer, L., \& Hutchings, M. (2000). Bettering yourself: Discourses of risk, cost and benefit in ethnically diverse, young working class participants' constructions of higher education. British Journal of Sociology of Education, 21(4), 555-574.

Armstrong, J. S. (2010). Persuasive advertising: Evidence-based principles. New York: Palgrave-Macmillan.

ASA. (2009). Adjudication on a complaint against the Department for Children, Schools and Families. London UK, Advertising Standards Authority, London, UK. Retrieved June 23, 2013, from http://www.asa.org.uk/ASA-action/ Adjudications/2009/10/Department-for-Children,Schools-and-Families/ TF ADJ 47146.aspx

ASA. (2010). Adjudication on a complaint against the University of Plymouth. Advertising Standards Authority, London, UK. Retrieved June 23, 2013, from http://www.asa.org.uk/ASA-action/Adjudications/2010/1/The-University-of Plymouth/TF ADJ 47932.aspx

ASA. (2013). Advertising Standards Authority, Archive database of adjudications and rulings. Advertising Standards Authority, London, UK. Retrieved June 23, 2013, from http://www.asa.org.uk/Rulings/Adjudications.aspx

Askehave, I. (2007). The impact of marketization on higher education genres. Discourse Studies, 9(6), 723-742.

Astore, W. (2009). The wider dimensions of academic integrity. International Journal for Educational Integrity, 5(2), 4-9.

Bennett, R., \& Kottasz, R. (2006). Widening participation and student expectations of higher education. International Journal of Management Education, 5(2), 47-65. 
Boush, D., Friestad, M., \& Rose, G. (1994). Adolescent skepticism toward TV advertising and knowledge of advertiser tactics. Journal of Consumer Research, 21(1), 165-175.

Bradley, J. (2012). Young people navigating the transition to university: Policy, context and influences. Educational and Child Psychology, 29(1), 101-110.

Briggs, S., \& Wilson, W. (2007). Which university? A study of the influence of cost and information factors on Scottish undergraduate choice. Journal of Higher Education Policy and Management, 29(1), 57-72.

Brockbank, L. (1996). Prospectus perspectives. Education Marketing, 5, 16-18.

Cheng, J., \& Marsh, H. (2010). National Student Survey: Are differences between universities and courses reliable and meaningful? Oxford Review of Education, 36(6), 693-712.

Claiborne, W. (2000, September 21). School's diversity too good to be true. Washington Post/San Francisco Chronicle. Retrieved September 23, 2013, from http://www.sfgate.com/education/article/School-s-Diversity-Too-Good-toBe-True-2737946.php

Cloud, M., \& Shepherd, G. (2012). Law deans in jail? Legal Studies Research Paper Series, Emory University School of Law No.12-199.

Connor, H., \& Dewson, S. (2001). Social class and higher education. DfES Report No267. London, Department for Education \& Skills.

Coughlan, S. (2008). Faculty in league table expulsion 25 th July 2008. Retrieved June 23, 2013, from http://news.bbc.co.uk/1/hi/education/7526061.stm.

Curtis, P., \& Meikle, J. (2007, July 10). The critical list: The two-year fight to name the universities facing financial collapse. The Guardian. Retrieved September 23, 2013, from http://www.theguardian.com/politics/2007/jul/10/ freedomofinformation.highereducation

Dean, D., \& Biswas, A. (2001). Third-party organization endorsement of products. Journal of Advertising, 30(4), 41-57.

El-Khawas, E. (1977). Better information for student choice: Report of the National Task Force. Washington, D.C.: American Association for Higher Education.

Gardener, D. (1975). Deception in advertising: A conceptual approach. Journal of Marketing, 39(January), 40-46.

George, W., \& Berry, L. (1981). Guidelines for the advertising of services. Business Horizons, 24, 52-56.

Gibbs, P. (2007). Does advertising pervert higher education? Journal of Marketing for Higher Education, 17(1), 3-11.

Glaser, B., \& Strauss, A. (1967). The discovery of grounded theory: Strategies for qualitative research. Chicago: Aldine.

Hartley, M., \& Morphew, C. (2008). What's being sold and to what end? The Journal of Higher Education, 79(8), 671-691.

Hastak, M., \& Mazis, M. (2011). Deception by implication: A typology of truthful but misleading advertising and labeling claims. Journal of Public Policy and Management, 30(2), 157-167.

HEA. (2012). Behavioural approaches to understanding student choice. York: The Higher Education Academy.

Hemsley-Brown, J. (2011). Market heal thyself: The challenges of a free market in higher education. Journal of Marketing for Higher Education, 21(2), 115-132.

IOE. (2011). Enhancing and developing the National Student Survey. London: Institute of Education.

Jongbloed, B., \& Koelman, J. (2000). Vouchers for higher education? Centre for HE Policy Studies, University of Twente, NL.

King, R. (1987). Painting the wrong picture. Currents, 13(1), 26-30.

Kintrea, K., StClair, R., \& Houston, M. (2011). The influence of parents, places and poverty on educational attitudes and aspirations. York: Joseph Rowntree Foundation. 
Klassen, M. (2001). Lots of fun, not much work and no hassles: Marketing images of higher education. Journal of Marketing for Higher Education, 10(2), 11-26.

Marsh, H. (2007). Student evaluations of university teaching: Dimensionality, reliability, validity, potential biases and usefulness. In R.P. Perry \& J.C. Smart (Eds.), The scholarship of teaching and learning in higher education: An evidence-based perspective (pp. 319-383). Dordrecht, The Netherlands: Springer.

Mittal, B. (1999). The advertising of services: Meeting the challenge of intangibility. Journal of Service Research, 2(98): 98-116.

Molesworth, M., Nixon, E., \& Scullion, R. (2009). Having, being and higher education: The marketisation of the university and the transformation of the student into consumer. Teaching in Higher Education, 14(3) 277-287.

Murray, J. (2012). Professional dishonesty: Do U.S. law schools that report false or misleading employment statistics violate consumer protection laws? Journal of Consumer \& Commercial Law, 15(3), 97-108.

O'Donohoe, S. (2001). Living with ambivalence: Attitudes to advertising in postmodern times. Marketing Theory, 1(1), 91-108.

Pippert, T., \& Matchett, E. (2010). Marketing diversity on campus. Paper presented to the American Sociological Association Meeting Atlanta Georgia.

Porter, T. (1995). Trust in numbers. Princeton, New Jersey: Princeton University Press.

Preston, I. (1989). The FTC's identification of implications as constituting deceptive advertising. University of Cincinnati Law Review, 57(4), 1243-1310.

Pugsley, L. (2004). The university challenge: Higher education, markets and social stratification. Cardiff: Ashgate.

QAA. (2008). Outcomes from institutional audits. Second Series. Gloucester, UK: Quality Assurance Agency for Higher Education.

QAA. (2011). Outcomes from institutional audit. Third series. Gloucester, UK: Quality Assurance Agency for Higher Education.

Reay, D., \& David, M. (2005). Degrees of choice: Class, race, gender and higher education. Stoke on Trent, UK: Trentham.

Renfrew, K., Davies, P., Baird, H., Hughes, A., Green, H., Mangan, J,. \& Slack, K. (2010). Understanding the information needs of users of public information about higher education: Report to HEFCE. Manchester: Oakleigh Consulting.

Richards, J. (1990). Deceptive advertising. Hillsdale, NJ: Lawrence Erlbaum.

Roberts, J. (2009). An author's guide to publication ethics. Headache, 49, 578-589.

Russo, J., Metcalf, N., \& Stephens, D. (1981). Identifying misleading advertising. Journal of Consumer Research, 8, 119-131.

Sawyer, K., Johnson, J., \& Holub, M. (2009). Decline in academe. International Journal for Educational Integrity, 5(2) 10-28.

Sharrock, G. (2010). Two Hippocratic oaths for higher education. Journal of Higher Education Policy and Management, 32(4), 365-377.

Stark, J., \& Marchese, T. (1978). Auditing college publications for prospective students. Journal of Higher Education, 49(1), 82-92.

Steele, K. (2007). Standing out on paper: Best practices in university viewbooks. Paper presented to the Atlantic Association of Registrars and Admissions Officers, Fredericton. NB Canada.

Steele, K. (2009). The 2009 crop of viewbooks, The Academia Group. Retrieved June 23, 2013, from www.academicagroup.com/node/8554.

Supiano, B. (2012, August 17). Emory University intentionally misreported admissions data, investigation finds. The Chronicle of Higher Education. Retrieved September 23, 2013, from http://chronicle.com/blogs/headcount/emory-uintentionally-misreported-admissions-data-investigation-finds/31215

Twain, M. (1906). Chapters from my autobiography. Retrieved June 23, 2013, from http://www.gutenberg.org/files/19987/19987.txt. 
UKIRO. (2009). Code of practice for research. London, UK: Research Integrity Office.

Vasagar, J. (2010, December 6). Twenty-one Oxbridge colleges took no black students last year. The Guardian. Retrieved September 23, 2013, from http:// www.theguardian.com/education/2010/dec/06/oxford-colleges-no-blackstudents

Veloutsou, C., \& Paton, R. (2005). Consultation and reliability of information sources pertaining to university selection: Some questions answered? International Journal of Educational Management, 19(4), 279-291.

Wager, E., \& Kleinert, S. (2011). Responsible research publication position statements. In T. Mayer \& N. Steneck (Eds.), Promoting Research Integrity in a Global Environment. Singapore: World Scientific Publishing.

Webster, D. (1992). Rankings of undergraduate education in US News \& World Report and Money. Change: The Magazine of Higher Learning, 24(2), 19-31.

Yalch, R., \& Elmore-Yalch, R. (1984). The effect of numbers on the route to persuasion. Journal of Consumer Research, 11(1), 522-527.

\section{About the Author}

John Bradley has worked as an educational psychologist in England, Hong Kong and Brunei. He was Principal Educational Psychologist and Head of Social Inclusion for Nottinghamshire County Council in England, prior to his retirement. He completed his doctorate at University of Nottingham as a (very) mature student, examining young people's ideas of 'going to university'. He now works part-time with university students with additional needs and undertakes independent research into university recruitment. 